\title{
MEN AND WOMEN IN THE TAGNAWA SYSTEM OF ILOCOS (PHILIPPINES)
}

\author{
Norma A. Esguerra \\ College of Engineering, University of Northern Philippines, \\ Tamag, Vigan City 2700 Ilocos Sur, Philippines \\ jafbkc@yahoo.com
}

\begin{abstract}
This research delves into a poverty alleviating way of life of the Ilokanos- the Tagnawa System. This practice is the coming together of men and women around the neighborhood to help one another during times requiring voluminous work, without thinking monetary remuneration in return. It identified the segment of population that had been practicing it and the occasions in their life as a community that have made this system very fructifying. Data gathering was done through interview with two (2) groups of respondents: the elderly and middle-aged adults in Ilocos Sur and Ilocos Norte, provinces of Region 1 where the original Iluko tribe reside. The data gathered from the interviews were further reinforced through readings and internet blogs. The real tagnawa system was practiced among the Ilokanos of yesteryears on various farming activities and during house construction, renovation and repair, while the modified tagnawa is applied during special events like weddings and funerals. Rendering of services in the original tagnawa spirit was free because there would be return services by those who were served. In the modified tagnawa, neighbors would share resources and services to somebody in need without expecting anything in return. Focusing on the interview with the elderlies who experienced the tagnawa being unveiled in the three (3) main Iluko occasions, the researcher was able to identify and appreciate innate Ilocano values and original Iloko terms which are already seldom used nowadays. This research tries to revive their use for the present generation to ponder upon.
\end{abstract}

Keywords: tagnawa, innammoyo, Iluko traits, kinawido, kinakirmet, kinamanagwaywayas, purok, self-help, men's roles, women's roles, culture

\section{Introduction}

Bayan is a Filipino term that refers to a nation, town or community. Bayanihan came from the root word bayani which first appeared in 1745 in a manuscript entitled "Vocabulario de la Lengua Tagala" by P. Juan de Noceda and P. Pedro de Sanlucar which means Obra Comun or group work (https://www.slideshare.net/jundumaug1/les son-3-filipino-values-bayanihan). A requisite of bayanihan is the presence of a group initiative to achieve a common particular objective or a common noble purpose and equitably sharing the fruits of labor. Another way of expressing it is "working together as a community" so that as a community, those residing within will reap and share in harvesting the goals achieved by that togetherness.

Accoding to Sylvia Guerrero, a social scientist, bayanihan embodies mutual sense of brotherhood and solidarity among co- equals, in facing concerns which may be physical or financial in nature.

Taken from another perspective, bayanihan is a unique way of showing heroism (bayani)- a different nature of helping others because one readily offers his/her own self, sometimes giving up one's life just to extend a helping hand. Usually, this kind of help trandscends beyond boundaries of personal or intimate relationships, depending upon the how sincere a person exercises his/her leadership or authority (Aguiling-Dalisay).

In the Tagalog speaking provinces, the term bayanihan is a common tradition being practiced when community members volunteer to help a family move to a new place. The process involves literally carrying the house to its new location. This is done by putting bamboo poles forming a strong frame to lift the stilts from the ground and carrying the whole house with the men positioned at the ends of each pole. The tradition also 
features a small fiesta hosted by the family to express gratitude to the volunteers.

The Filipino culture could be best expressed and understood with bayanihan as its core. A neighbor in need is the concern of the whole community. The whole neighborhood believes that workload is lessened and job is easier if done together.

This practice is being observed all over the Philippines, in different terminologies, like tiklos by the Waray people of Leyte, pintakasi in Samar, kapanyidungan by the Ivatans of Batanes. In Ilocos, it is called tagnawa.

Since time immemorial, poverty has been the most challenging problem to solve. But not in the northern part of this countrythe land of the sturdy, frugal, and cooperative Ilocanoes with their "United, We Stand; Divided, We Fall" ideology embodied in their practice of the tagnawa system.

A glimpse of the past recalls the effectiveness of this Ilokano value among households situated in barangays which was originally called "purok". The households may be relatives or just mere friends. Living in clusters keep them solid at all times, but even more solid during times of calamity and undesirable conditions like sickness, death and the like.

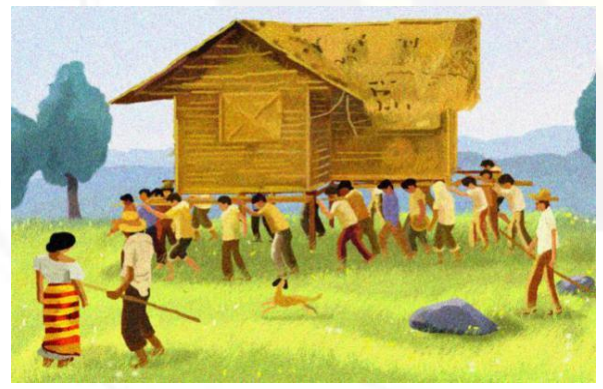

Fig.1. A mural painting by a Filipino Artist Carlos "Bodong" Francisco and painting by Joselito E. Barcelona on bayanihan.

The Iluko culture is a rich blend of religion, literature, tradition, practices and built environment. The tagnawa system, as one of the most valuable character of Ilocanoes, encompasses both tradition, practices and built environment.

Generally, this research tries to reminisce the tagnawa system of Ilocos, and to reconnect it to the present. To attain this, the determination of the following would specifically bring about the realization of the general objective: 1) the concept of tagnawa system among the respondents- the elderly and the middle-aged adults; 2) identification of activities done by the Ilokano men and women during farming, wedding, house construction and repair, and funeral; 3) the roles played by the Ilokano men and women in the tagnawa system; and 4) the challenges of the tagnawa system.

\section{Methods}

There are some readings collected that document the practice of bayanihan in general.

The concept of bayanihan is traced back in the country's tradition which can be observed in rural areas, wherein the town's people were asked especially the men to lend a hand to a family who will move into a new place. The relocation does not only involves moving the family's personal belongings but most importantly it concerns the transfer of the family's entire house to a new location. A traditional Filipino house (Bahay Kubo) is made of light indigenous materials such as bamboo and nipa, cogon or anahaw leaves. https://themixedculture.com/2013/09/25/filip inos-bayanihan/ accessed August 1, 2017.

The origin of the term bayanihan can be traced from a common tradition in Philippine towns where community members volunteer to help a family move to a new place. The process involves literally carrying the house to its new location. This is done by putting bamboo poles forming a strong frame to lift the stilts from the ground and carrying the whole house with the men positioned at the ends of each pole. The tradition also features a small fiesta hosted by the family to express gratitude to the volunteers. http://en.wikipilipinas.org/index.php/Bayani han accessed August 1, 2017

The idea of cooperativism is a common knowledge. In one case about land dispute, where one filed a claim of ownership over a piece of land, and one evidence presented was his tilling of the land, with a number of farm laborers tending to the various farming procedures, which was narrated to be of the bayanihan spirit. The judge pronounced this court ruling. The "bayanihan" is a laudible Philippine cooperative practice, specially true in rustic areas. The members of the bayanihan are not tenants, they do not receive pay and their 
work are utilized on temporary basis." (court ruling, De Guzman vs Paner, 1962).

A mural by Filipino National Artist Carlos "Botong" Francisco and painting by Joselito E. Barcelona (Figure 1) illustrates bayanihan in the actual act. This painting is the illustration of bayanihan among the Tagalog-speaking provinces.

Though an indigenous Filipino trait, bayanihan is practised with different spirits worldwide, according to Gertrudes R. Ang, another social scientist (Philippine Quarterly on Culture and Society, 1979). Her article was entitled "Bayanihan Spirit: Dead or Alive? It is a question she asked in the late '70's, when she presented two articles published in the Philippines Express Daily, a newspaper circulating everyday at that time dated May 6, 1978. Here, researchers from the University of the Philippines were studying the anthropology of cooperation. They found out that in the barrio of Ilocos Sur, where they conducted the study, there was disintegration of traditional labor exchange, which means that the people had adopted cash economy. The barrio work brigade that used to spearhead the core processes of damayan, no longer existed. It was believed that the introduction of the Virginia tobacco industry induced the shift from the damayan spirit to the cash-first economy. Tobacco growers hired men to do the work from planting to harvesting. Farming and housebuilding which were the central activity of the barrio folks on the tagnawa system, were slowly replaced by another work brigade- men hired as carpenters, or other related jobs, by the better offs and get cash in return. The researchers further theorized that if this was happening in that barrio, it could have been happening in other parts of the province or even in the country. With this scenario, the bayanihan spirit had died down.

Another internet blog said those bayanihan days are already gone. The usual bahay kubo light houses are now replaced by concrete infrastructures. Rural jungle areas are now being replaced by urban jungles. In as much as there are physical changes in the environment, there is a dramatic change in the attitudes and disposition of the Ilocanos. They have become egoistic and egocentric, in other words, selfish and makasarili. Group efforts have become very rare, and if ever such is established, sustaining such group efforts is even harder. One devastating part of the Iluko culture influenced by the Spanish era is crab mentality.

However, Ang, through the July 4, 1978 issue of the same newpaper, presented another scenario. She presented other instances that the bayanihan spirit is still alive.

Still with the question whether the bayanihan spirit is dead or alive, the answer is obvious with the Typhoon Yolanda incident. It is still alive! People all over the country lent helping hands to the victims of the disaster. Many replied positively that the bayanihan spirit is still alive. http://www.philstar.com/inboxworld/514984/what-can-you-say-aboutbayanihan-spirit-filipino, accessed August 15, 2017.

\subsection{Research Design}

The study is qualitative in nature, descriptive in approach. Findings and outputs were derived from the actual experiences shared by the respondents.

\subsection{Population}

20 middled-aged adults and 32 elderly men and women aging 70 and above were randomly selected from three (3) chosen towns of Ilocos Sur and Ilocos Norte were the targeted respondents. However, the researcher encountered one knowledgeable man to the practice, he was included as a respondent having shared his first hand experience. Other elderly encountered outside the targeted towns were also taken. See Table 1.

Table 1. Breakdown of Respondents

\begin{tabular}{lcc}
\hline Particulars & $\begin{array}{c}\text { Target } \\
\text { Number of } \\
\text { Responde } \\
\text { nts }\end{array}$ & $\begin{array}{c}\text { Actual } \\
\text { Number } \\
\text { of } \\
\text { Respond } \\
\text { ents }\end{array}$ \\
\hline a. Ilocos Sur & 30 & 32 \\
\hline Sto. Domingo & 10 & 12 \\
\hline Narvacan & 10 & 9 \\
\hline Santa & 10 & 1 \\
\hline Galimuyod & 10 & 10 \\
\hline b.Ilocos Norte & & 3 \\
\hline Batac & & 7 \\
\hline Dingras & 10 & 10 \\
\hline Sarrat & & \\
\hline
\end{tabular}




$\begin{array}{lll}\text { Total } & 40 & 52\end{array}$

\subsection{Data Gathering Technique}

Data was gathered by means of structured interview. A questionnaire was prepared as guide, though relevant follow up questions were asked. With an acquaintance in the area as lead person, each respondent was reached in his/her respective residence. Ethics was strictly observed, respect to the elderly and middle-aged adults was assured. The responses were all welcomed, processed, noting all the similar and varying ones, then drew a general statement therefrom.

\subsection{Operational Definition of Terms}

For the readers' easier grasp of the terms used, the following key words are defined as they were used in the study: Real tagnawa event - an informal grouping or association of a number of Ilokanos where they take turns in conducting their labor intensive project common to all members to get rid of paying for the remuneration of those involved in the project (other term is Innammoyo) Modified tagnawa event - the act of helping a neighbor in need of physical or materials help due the occurrence of a favorable or unfavorable situation. This has the same spirit as bayanihan from the perspective of other cultures.

Elderly - respondents aging beyond 60 years old. Middle-aged adults respondents aging between 40-59 years old. Challenges - those events which led to the decline of the practice of tagnawa. Gender stereotypes - these are generalized traditional activities already attached to men and women as if doing untraditional roles by the stronger sex would already cause dishonor to the image of the stronger sex. Men's Roles responsibilities expected to be done by the men.

Women's roles - responsibilities expected to be done by the women.

\section{Results and Discussions}

\subsection{On the Profile of the Respondents}

A look at the profile of the respondents, taken from the parameters of age, educational attainment, civil status and sex, would reveal the following data: As to Age. The age bracket 41 to 50 years old have the most respondents (15 out of 52 or $28.85 \%$ ), while 14 , or $26.92 \%$ are those aging older than this age bracket. Only one (1) respondent is 60 years old.

As to Educational Attainment. The respondents who finished College dominated the number of respondents (15 out of 52 or barely $29 \%$ ), while those who just had years in college came next (11 out of 52, or $21.15 \%)$. Ten or $19.23 \%$ are on the college level. $13.46 \%$ are Elementary and High School Graduates each. The least are those who just finished several years in High School, but did not graduate.

As to Civil Status. Majority (39 or $75 \%$ ) of the respondents are married. Only 11 are widows/widowed, while only one respondent claim himself/herself to be single or separated. As to Sex. 30 or $57.69 \%$ of the repondents are male, and $12(42.31 \%)$ are female.

Table 2. The Personal Profile of the Respondents

\begin{tabular}{|c|c|c|}
\hline A. As to Age & Frequency & Percentage \\
\hline $31-40$ & 10 & 19.23 \\
\hline $41-50$ & 15 & 28.85 \\
\hline $51-60$ & 1 & 1.92 \\
\hline $61-70$ & 6 & 11.54 \\
\hline $71-80$ & 14 & 26.92 \\
\hline$>80$ & 6 & 11.54 \\
\hline Total & 52 & 100.00 \\
\hline \multicolumn{3}{|c|}{ a. As to Educ Attainm't } \\
\hline College Grad & 15 & 28.85 \\
\hline College Level & 10 & 19.23 \\
\hline HS Graduate & 7 & 13.46 \\
\hline HS Level & 2 & 3.85 \\
\hline Elem Graduate & 7 & 13.46 \\
\hline Elem Level & 11 & 21.15 \\
\hline Total & 52 & 100.00 \\
\hline \multicolumn{3}{|l|}{ As to Civil Status } \\
\hline Married & 39 & 75.00 \\
\hline Widow & 11 & 21.15 \\
\hline Single & 1 & 1.92 \\
\hline Separated & 1 & 1.92 \\
\hline Total & 27 & 100.00 \\
\hline \multicolumn{3}{|l|}{ As to Sex } \\
\hline Male & 30 & 57.69 \\
\hline Female & 22 & 42.31 \\
\hline Total & 52 & 100.00 \\
\hline
\end{tabular}




\subsection{On the Concept of Tagnawa System among the Respondents- The Elderly and the Middle-Aged Adults}

\subsubsection{The Elderly}

The concept of tagnawa was so clear to the elderly group. They knew it right from the first time that the word was uttered by the interviewers. The idea of paying daily wage earners was not yet part of their options. Their memories were filled with first hand experiences about the conduct of this Ilocano practice which was very popular before and after the Second World War, and extending several decades beyond. However, the practice slowly died when the tobacco industry started to boom in Ilocandia.

Some popular traits are associated with the Ilocanos. (ejournals.ph/issue.php?id=663). They are known for their frugality (kinakirmet) and they tend to be self-reliant to some extent (kinamanagwaywayas). However, this trait has a limitation because there are things that they could not do alone, like the conduct of farming and house repair or construction. It was also identified that Ilocanos are known to be ingenious (kinawido). The concept of tagnawa as a self-help mechanism is an evidence to this ingenuity. To them, it was their way of life to face the rigorous task of farming and house construction or repair. They had to resort to this mechanism to survive the critical months of a year-round struggle to make both ends meet. It was a way to ease out their burden from assuring their supply of rice which they could only get from their harvests. Farming was their only source of livelihood.

\subsubsection{The Middle-Aged Adults}

The concept of tagnawa is not anymore known to about seventy percent of the number of the middle-aged adults interviewed. There were times that they hear the word, but they no longer know how this practice was conducted. Nevertheless, the rest of the respondents still had some secondhand experience about this practice.

The elderlies commonly observe that distinct practices that showed strong positive Ilokano traits as a race are gradually vanishing.

\subsection{On the Identification of Activities Done by the Ilocano Men and Women per Tagnawa Event}

3.3.1. During the Farming Season.

Table 3 shows the identified activities during the farming season:

Table 3. Tagnawa Activities during the Farming Season

\begin{tabular}{|c|c|c|}
\hline $\begin{array}{c}\text { Activities } \\
\text { Done by the } \\
\text { Men }\end{array}$ & $\begin{array}{l}\text { Activities } \\
\text { Done by the } \\
\text { Women }\end{array}$ & $\begin{array}{l}\text { Activities } \\
\text { Done by } \\
\text { Both }\end{array}$ \\
\hline $\begin{array}{l}\text { plow the } \\
\text { planting } \\
\text { site }\end{array}$ & $\begin{array}{l}\text { uproot the } \\
\text { young rice } \\
\text { plants from } \\
\text { the seedbed }\end{array}$ & $\begin{array}{l}\text { bind the } \\
\text { uprooted } \\
\text { rice } \\
\text { seedlings } \\
\text { into carrying } \\
\text { sizes }\end{array}$ \\
\hline $\begin{array}{l}\text { harrow the } \\
\text { plowed area }\end{array}$ & $\begin{array}{l}\text { cook food for } \\
\text { the rice } \\
\text { planters }\end{array}$ & \\
\hline $\begin{array}{l}\text { planting } \\
\text { rice }\end{array}$ & $\begin{array}{l}\text { bind the } \\
\text { uprooted rice } \\
\text { seedlings into } \\
\text { carrying sizes }\end{array}$ & \\
\hline $\begin{array}{l}\text { bind the } \\
\text { uprooted } \\
\text { rice } \\
\text { seedlings } \\
\text { into } \\
\text { carrying } \\
\text { size }\end{array}$ & & \\
\hline $\begin{array}{l}\text { transport } \\
\text { the binded } \\
\text { uprooted } \\
\text { rice } \\
\text { seedlings } \\
\text { using the } \\
\text { sled or cart }\end{array}$ & & \\
\hline
\end{tabular}

\subsection{2. During \\ House}

\section{Repair/Construction}

Being the same in standard and status of living, they live in nipa huts (or kalapaw) which had to be maintained annually. While waiting for their rice plants to bear fruit and be harvested, it would be the turn of their kalapaws to be repaired/reconstructed after a year of wear and tear from the rains or storms. This would need again another schedule as to when would be the repair or reconstruction of their individual nipa huts. 
Table 4 shows the activities identified by the respondents during the conduct of repair/construction.

Table 4. Tagnawa Activities during House Repair/Construction

\begin{tabular}{lll}
\hline $\begin{array}{l}\text { Activities Done } \\
\text { by the Men }\end{array}$ & $\begin{array}{l}\text { Activities } \\
\text { Done by the } \\
\text { Women }\end{array}$ & $\begin{array}{l}\text { Activities } \\
\text { Done by } \\
\text { Both }\end{array}$ \\
\hline $\begin{array}{l}\text { cut bamboos } \\
\text { and structural } \\
\text { wood }\end{array}$ & $\begin{array}{l}\text { prepare } \\
\text { snacks }\end{array}$ & \\
\hline $\begin{array}{l}\text { cut and dry } \\
\text { cogon grass for }\end{array}$ & $\begin{array}{l}\text { cook food } \\
\text { for the } \\
\text { woofing }\end{array}$ & workers \\
\hline excavate holes & \\
\hline $\begin{array}{l}\text { tie dried cogon } \\
\text { grass into palm- } \\
\text { cup sizes }\end{array}$ & \\
\hline $\begin{array}{l}\text { fasten palm-cup } \\
\text { cogon sizes } \\
\text { between two } \\
\text { bamboo strips }\end{array}$ & \\
\hline
\end{tabular}

Tables 5 and 6 reveal the identified activities of modified tagnawa events. They are quite different from the purpose and conduct of the real tagnawa practice, in sense that, there are no more agreements as to scheduling of the work because such events are unpredictable.

\subsubsection{During Weddings}

Table 5 shows the activities identified by the respondents being conducted during weddings.

Table 5. Tagnawa Activities during Weddings

\begin{tabular}{lll}
\hline $\begin{array}{l}\text { Activities } \\
\text { Done by } \\
\text { the Men }\end{array}$ & $\begin{array}{l}\text { Activities } \\
\text { Done by the } \\
\text { Women }\end{array}$ & $\begin{array}{l}\text { Activities } \\
\text { Done by } \\
\text { Both }\end{array}$ \\
\hline $\begin{array}{l}\text { assemble } \\
\text { sheds for } \\
\text { guests }\end{array}$ & $\begin{array}{l}\text { clean the } \\
\text { wedding } \\
\text { reception area }\end{array}$ & cook food \\
\hline $\begin{array}{l}\text { prepare } \\
\text { firewood }\end{array}$ & $\begin{array}{l}\text { hang crocheted } \\
\text { curtains to } \\
\text { make the } \\
\text { reception area }\end{array}$ & $\begin{array}{l}\text { hang } \\
\text { crocheted } \\
\text { curtains to } \\
\text { make the } \\
\text { reception }\end{array}$ \\
\hline
\end{tabular}

\begin{tabular}{lll}
\hline & $\begin{array}{l}\text { more } \\
\text { presentable }\end{array}$ & $\begin{array}{l}\text { area more } \\
\text { presentable }\end{array}$ \\
\hline $\begin{array}{l}\text { hang } \\
\text { crocheted } \\
\text { curtains to } \\
\text { make the } \\
\text { reception } \\
\text { area more } \\
\text { presentable }\end{array}$ & $\begin{array}{l}\text { borrow and } \\
\text { return plates, } \\
\text { bowls, spoons, } \\
\text { forks }\end{array}$ \\
\hline $\begin{array}{l}\text { butcher } \\
\text { pigs }\end{array}$ & cook food \\
\hline $\begin{array}{l}\text { borrow and } \\
\text { return } \\
\text { tables, } \\
\text { chairs and } \\
\text { large } \\
\text { cooking } \\
\text { vessels }\end{array}$ & serve the \\
\hline guests \\
\end{tabular}

\subsubsection{During Wakes and Funerals.}

Death is one unexpected and unfavorable occurrence in the life of the Ilocanos. They can't do away with it, so, they just accept the reality. They believe that the effect of sorrow could be made lighter when shared among themselves, so with the activities that are inherent to the bereaved family.

Table 6 shows the identified activities done by the neighbors during wakes and funeral events.

Table 6. Tagnawa Activities during Wakes and Funerals

\begin{tabular}{|c|c|c|}
\hline $\begin{array}{l}\text { Activities } \\
\text { Done by } \\
\text { the Men }\end{array}$ & $\begin{array}{l}\text { Activities } \\
\text { Done by the } \\
\text { Women }\end{array}$ & $\begin{array}{l}\text { Activities } \\
\text { Done by } \\
\text { Both }\end{array}$ \\
\hline \multicolumn{3}{|c|}{ During the wake } \\
\hline $\begin{array}{l}\text { assemble } \\
\text { sheds for } \\
\text { guests }\end{array}$ & $\begin{array}{l}\text { do the home } \\
\text { chores of the } \\
\text { bereaved } \\
\text { family }\end{array}$ & $\begin{array}{l}\text { join the } \\
\text { vigil every } \\
\text { night }\end{array}$ \\
\hline $\begin{array}{l}\text { borrow } \\
\text { tables, } \\
\text { chairs }\end{array}$ & $\begin{array}{l}\text { boil water for } \\
\text { serving coffee }\end{array}$ & \\
\hline $\begin{array}{l}\text { borrow and } \\
\text { return large }\end{array}$ & $\begin{array}{l}\text { pray for the } \\
\text { repose of the }\end{array}$ & \\
\hline
\end{tabular}




\begin{tabular}{lll}
\hline $\begin{array}{l}\text { cooking } \\
\text { vessels }\end{array}$ & $\begin{array}{l}\text { soul of the } \\
\text { dead }\end{array}$ \\
\hline $\begin{array}{l}\text { join the } \\
\text { vigil every } \\
\text { night }\end{array}$ & $\begin{array}{l}\text { join the vigil } \\
\text { every night }\end{array}$ \\
\hline \multicolumn{3}{c}{ During the Funeral } \\
\hline $\begin{array}{l}\text { prepare } \\
\text { firewood }\end{array}$ & $\begin{array}{l}\text { borrow plates, } \\
\text { bowls, } \\
\text { spoons, forks }\end{array}$ & $\begin{array}{l}\text { to be } \\
\text { cooked }\end{array}$ \\
\hline $\begin{array}{l}\text { butcher } \\
\text { pigs }\end{array}$ & cook food & cook food \\
\hline $\begin{array}{l}\text { slice meat } \\
\text { to be } \\
\text { cooked }\end{array}$ & $\begin{array}{l}\text { slice meat to } \\
\text { be cooked }\end{array}$ & $\begin{array}{l}\text { join the } \\
\text { funeral } \\
\text { procession }\end{array}$ \\
\hline $\begin{array}{ll}\text { cook food } \\
\text { serve those } \\
\text { who join the } \\
\text { funeral }\end{array}$ & \\
\hline $\begin{array}{l}\text { join the } \\
\text { funeral } \\
\text { procession }\end{array}$ & $\begin{array}{l}\text { join the } \\
\text { funeral } \\
\text { procession }\end{array}$ \\
\hline
\end{tabular}

\subsubsection{On the Roles Played by the Ilocano Men and Women in the Tagnawa System}

Gender sterotyping is generalizing (http://www.healthguidance.org/entry/15910 /1/List-of-Gender-Stereotypes.htmlis) the role of boys and girls, men and women. In the study, there was a perceived strong gender stereotyping among the Ilocano men and women involved in tagnawa events. The roles they played were the typical roles of men and women prior to the passage of RA 7192, the Gender and Development Act, when women were still the second class citizens, whose skills and capacities were not yet recognized.

\subsubsection{During the Farming Season}

Only the males were identified doing plowing and harrowing, and transporting rice seedlings to the fields, and planting rice. No one of the respondents claimed that these were done by the females. The women's distinct role was to pull the young seedlings to be transplanted. In other words, farming was associated as an activity for men in their stereotype role as bread winners. Women, even though they also had their activity of pulling the young rice seedlings during the farming season, and cooking food for the men planters, they were just doing a minor activity in support to their husbands. This role is better said as care giver, or one providing support or assistance for outside help.

3.3.5.2.During House Repair/Construction.

No female were observed by the respondents to be involved in house repair or construction. They only identified the males to be doing this, which dates back to the original gender stereotype- men being eyed as protector of the family including the infrastructure that houses the members. It was the duty of the men to fix their places of residence, while their wives were just providing support, like cooking lunch for the workers, then serving the prepared food.

\subsubsection{During Weddings/Wakes and} Funerals.

The activities of the men during weddings were the strenuous onesconstructing sheds, borrowing heavy cooking utensils, butchering pigs or cows, while the women were doing the lighter activitiesborrowing plates, bowls, spoons, forks and glasses, cleaning the house, cooking. These are manifestations of the usual characteristics of men as strong, while the women, being of the fairer sex, are not that strong.(https://www.slideshare.net/ribenaber ry/traditional-and-non-tradition-roles-ofmales-and-females). Seen from another perspective, Ilokano men generally subscribe to the practice of being gentlemanly and responsible. Ilokano husbands care for their wives. Assuming all tough jobs is a clear manifestation of a caring husband.

\subsubsection{The Challenges of the Tagnawa System}

When four to five decades of years ago, the tagnawa system was a vibrant self-help mechanism to establish a non-monetary deployment of labor force, nowadays, its spirit had died down. The following systems were the respondents' perceived reason why the tagnawa spirit has vanished.

\subsubsection{Farming}

When asked if the tagnawa practice is still being done during the farming season, all 
of the respondents answered "not anymore (saan tattan)". The Ilokanos do not anymore come together during the farming season to strategize their rice planting schedule because they have become somehow, self-reliant. Viewed at a negative effect, nobody now is willing to work for others for free.

The reason given by the respondents for Ilokano farmers not organizing anymore under the tagnawa spirit is due to the presence now of technology, which could already set individual farmers to become independent. They could already do farming without fellow farmers by using their kuligligs for the plowing and harrowing activities. Also, the kuliglig has substituted the cart pulled buy a cow or carabao to transport farming paraphernalia from the house to the rice paddies. Ilokano families could now reach their fields, then go back home after work faster through the gasolinedriven kuliglig. Planting rice, though not yet mechanized, already employed rice planters paid on daily basis. Daily standard rates for farm workers are now standardized by the Department of Labor and Industry. Moreover, the Local Government Units are giving technical and financial assistance to the farmers. Technical assistance comes in by the supervision of the Municipal Agriculture Officer (MAO) and Field Technicians to help control pests that ruin vegetation or provide proper advise on the type of fertilizer or spray to be applied to the plants. Financial assistance, on the other hand, is done by giving out loans and free fertilizers to the farmers. In some municipalities, there are also insurance assistance that will be used in case there will be no crops harvested- a way of managing bankruptcy among farmers when disasters, like typhoon, flood or drought spoil crops.

\subsubsection{House Repair/Construction}

The respondents, when asked if the tagnawa system is still being adopted up to this time, all of the elderly answered "not anymore (saan tattan)". When before, the construction materials would necessitate just the bamboo with its different species, like putek for the columns or posts, ugguad, for the beams, windows and walls, the introduction of cement, sand, gravel and concrete products already stopped the use of bamboo. The farmers had decided to put up permanent dwelling houses, unlike the bamboo which needs repair every year. The farmers no longer set aside a time to repair their kalapaws after every planting season, because their houses are already standing as temporary to permanent. The idea of constructing then was not anymore the same. Now, most Ilokano heads of the family prefer their residences to be put up by contractors already, owing to the fact that these groups of businessmen know more in the field of constructing modern houses.

\subsubsection{Wedding/Wakes and Funerals.}

The parties of the bride and groom, during those days need companions in preparing their respective homes before the wedding, and much more so with the foods to be served during the wedding day. Today, it was observed by the respondents that only those brides and grooms who prefer to set own their residences as their wedding reception, would experience the modified tagnawa. Ilokanos now tend to work on their own, trying to get rid of help because they do not want to be disturbing the precious moments of others. It has been an increasingly famous practice to conduct occasions like wedding, birthdays, baptisms, even funeral receptions, by hiring a catering group to prepare the food and the venue, then to clean utensils and other tools used. It was then part of the tagnawa to pool resources so that enough plates, bowls, platters, glasses, spoons and forks, and cooking utensils were ready prior to the event, then return them again afterwards. Now, there are groups who do this as business.

In short, emerging technologies and businesses brought a change in the cooperative spirit of the Ilokanos. The respondents explained that nowadays, people look at the practical side of things. Why still bother themselves organizing a schedule to plow, harrow then plant rice in each other's field when they could already do the works 
simultaneously through modern farm implements? Why burden themselves constructing a house using their crude tools and gadgets, when there are already specialized groups putting up structures faster and better? Why still tire themselves in pooling in plates, spoons, forks, drinking glasses, and the like, then return them again after the event, when there are already ready groups doing this to make money? The Ilokano customs and traditions have already been penetrated by external forces that have caused their disintegration!

\subsubsection{Other Related Information}

\subsubsection{The Existence of Informal Associations}

There was an informal structure of the neighbors in a purok who enjoin themselves in the group work. The neighborhood was composed mostly of relatives. Only a few would be mere friends, or kumpare, kumare in a cluster of houses.

According to one respondent, those involved in the innammoyo or tagnawa practice, particularly in farming and house repair/construction activities, were united with the bounds of implied membership in an informal association. They belonged to the same class, more or less residing in similar dwelling styles. They would come together to plan out how they would schedule their farming activities on rotation basis, and each would take turn being assisted. All of the male respondents signified their direct participation to the tagnawa practice.

As already mentioned earlier, the Ilocanos are ingenious people. They had been practicing an informal association, usually composed of individuals with the same concerns and same state of life. If the concerns are common among them, they had the same needs, same standard of living, and the same aspirations in life. With the informal group, they would meet together and thresh out how to solve their common concerns. Usually, this concern was on farming. After they had expressed membership to a group, with a leader which would naturally stand out from among themselves, they would plan out how to schedule farm preparations (pulling young rice seedlings, plowing and harrowing the fields) and planting of rice such that they could rush the planting with the available rain water. They would set dates as to when would be the farm preparation and rice planting schedule of each member- activities were done together, to one member after another, until everybody had finished farming.

If somebody did not signify membership, he/she won't be assisted. This would imply that there is exclusivity of the granting of assistance- it is only for the members.

The practice of coming together for a common goal was done the whole year round. After the farming season, the tagnawa members would again call for another activity- house repair or construction. Because they had almost similar dwelling units, with the typical kalapaw or nipa hut, repair was necessary every year. Again, they would schedule the repair/construction among the members, on a rotation basis. Depending upon the extent of damage on their simple dwelling units, they would try to finish this activity in time for the forthcoming harvesting season.

\subsubsection{The Categories of the Tagnawa}

There were (2) identified real tagnawa events: a) during farming and b) during house repair and construction. The other two (2) were offshoots, or the modified tagnawa events: c) during wedding, and d) during wakes and funerals. These were activities that express the Ilocanos' innate spirit for cooperativism and volunteerism. At present, it is a calling for social responsibility. The activities were done without obliging the person helped to pay the services within a prescribed period.

During unforeseen favorable or unfavorable events in the life of the neighbors, they do activities that would help such. This does not anymore necessitate an informal grouping to receive equal benefit, but this is done to help a neighbor in need. A desirable happening may be weddings, while an unfavorable event could be the sudden 
death of a neighbor, which could be a friend or relative.

\subsubsection{Kalapaw Structure}

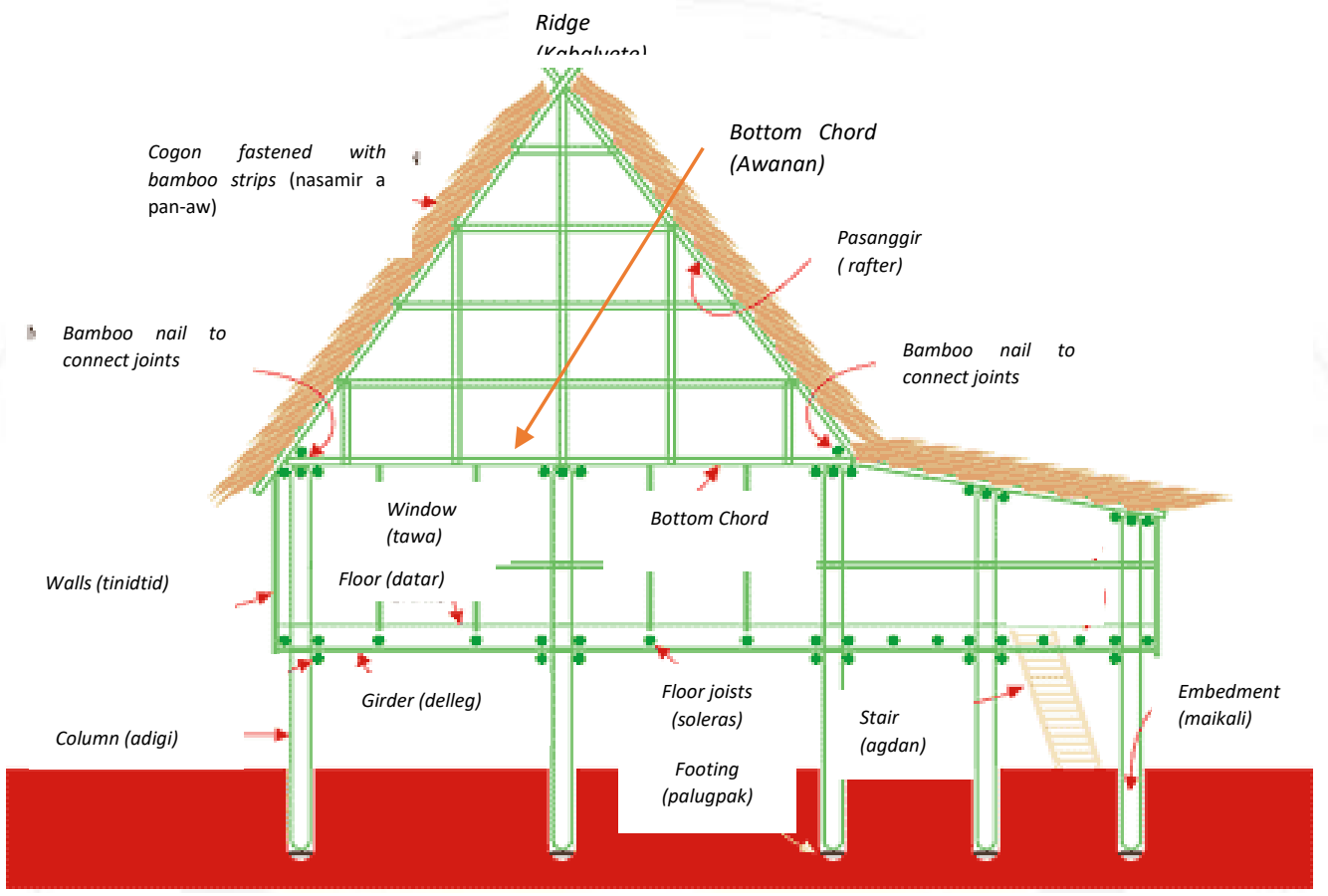

Fig. 2. The skeletal framework of a bahay kubo (kalapaw) showing its parts with lloko terms.

As deciphered from the interviews, there were construction foremen before, who directed the repair/construction of the nipa huts. Comparable to the architectural/structural plans being prepared today, with indicated modern construction terms, the forefathers had their own version of Iloko construction terms. Please refer to Figure 2.

\subsubsection{Original Iluko Terms}

The researcher found the following Iluko terms seldom used nowadays during the conduct of interview. Recalling them through this research would be a brilliant strategy to continue their usage.

\begin{tabular}{ll}
\hline $\begin{array}{c}\text { Identified } \\
\text { Tagnawa } \\
\text { Activity }\end{array}$ & Brief Description \\
\hline \multicolumn{2}{c}{ Panagtalon (Farming) } \\
\hline
\end{tabular}

Agsekka This farming activity was identified as an activity of the women. They pull young palay seedlings from the seedbed prior to the planting.

Agkerker This could be done by both men and women. It is the act of binding the pulled out rice seedlings into palm-cuff-sizes to facilitate their transport to the planting area.

Agarado The act of tilling, turning the soil by the use of this farm implement, consisting of a strong blade attached to a curved metal handle, then pulled by a cow or carabao. This is the plow.

Agpak-ol The act of softening the tilled surface of the soil excavated after plowing using horizontally laid wood or metal with spikes to form a rake to remove grasses from the planting area. 


\begin{tabular}{cl}
\hline \multicolumn{1}{c}{ Panaglagda/Panagbalay (House } \\
Repair/Construction)
\end{tabular}

\section{Conclusions}

From the foregoing discussions, the following were excerpted as generalizations:

1. The system, both the real and the modified scenarios, depicts men as the stronger sex, the women as the weaker sex, also assuming traditional roles as bread winner and protector of the family for the men, as housekeeper and care giver, for the women.

2. The Ilocanos' tagnawa system has two categories: the real tagnawa system which necessitates the association of families with more or less similar concerns, so as to maximize the selfhelp mechanism; while the modified tagnawa is just the same popular bayanihan concept known worldwide- a social responsibility of the better-offs for those in need.

3. The real tagnawa scenario was an induced self-help mechanism of the Ilocanos out of their inherent ingenuity for community organizing to strategize the conduct of labor intensive projects without monetary expenditures.

4. The real tagnawa spirit has dwindled because there are already options of Ilocanos for self-reliance and interdependency, from the introduced technology and modern concepts of business undertakings like contracting for house construction and catering services for special events, like weddings, baptisms, debuts, anniversaries, birthdays, and funerals.

5. There existed a crude kalapaw structure from which modern plans were patterned, another manifestation of the Ilocano ingenuity.

\section{Recommendations}

The researcher has the following to recommend for a better output of the study:

1. Some scenarios of the tagnawa may be preserved for the millennial individuals to ponder upon, by the use of sketches depicting the activities.

2. The concept of the real tagnawa may still be revived for the sake of self-help and poverty alleviation strategies.

3. Iluko terms may be perpetuated by the construction of technical museums to portray where, how and when these terms were used.

\section{References}

ejournals.ph/issue.php?id=663, accessed August 20, 2017

http://www.healthguidance.org/entry/15910/ $\underline{\text { 1/List-of-Gender-Stereotypes.htmlis, }}$ accessed August 20, 2017

https://www.slideshare.net/ribenaberry/tradit ional-and-non-tradition-roles-of- 
males-and-females accessed August

20, 2017

https://themixedculture.com/2013/09/25/filip

inos-bayanihan/ accessed August 1, 2017

http://en.wikipilipinas.org/index.php/Bayani han accessed August 1, 2017

http://www.philstar.com/inboxworld/514984/what-can-you-sayabout-bayanihan-spirit-filipino accessed August 15, 2017

https://www.slideshare.net/jundumaug1/less on-3-filipino-values-bayanihan

Court Ruling, De Guzman vs Paner, 1962

Carlos "Botong" Francisco, Filipino National Artist

Joselito E. Barcelona, Filipino Painter

Gertrudes R. Ang, The Bayanihan Spirit: Dead Or Alive?, Philippine Quarterly of Culture and Society, Vol. 7, No. 1/2

(March-June 1979), pp. 91-93

\section{Acknowledgments}

The author wishes to acknowledge the following for their invaluable contributions to this study:

1. Engr. Carl Lontoc for the computer-aided drawing of the kalapaw structure;

2. The University Research Office, headed by Ms. Petronila Florendo, for the airfare in presenting this research to NAKEM International, held at Honolulu, Hawaii in November 2017, and Dr. Marlou Sevilla, Chair of the In-house Review Committee, together with the Panel of Evaluators, Dr. Marie Rose Rabang, Dr. Eleanor Belizar, and Dr. Dea Meir Tacbas for the gender component.

3. The Center for Gender and Development, headed by Dr. Alegria Oandasan, for funding the study, and her staff in helping me out in the questionnaires and financial transactions.. 